\title{
Bioavailability of Agricultural Pesticides on the Land Snails in the Commune of Kérou in the North of Benin
}

\author{
Fadéby Modeste Gouissi*, Afouda Esaïe Adimi \\ Department of Management of Natural Resources (AGRN), Water and Soil Engineering, Faculty of Agronomy (FA), University of \\ Parakou (UP), Parakou, Benin \\ Email: ^gouissi@yahoo.fr
}

How to cite this paper: Gouissi, F.M. and Adimi, A.E. (2019) Bioavailability of Agricultural Pesticides on the Land Snails in the Commune of Kérou in the North of Benin. Open Journal of Soil Science, 9, 103-112. https://doi.org/10.4236/ojss.2019.97007

Received: July 1, 2019

Accepted: July 28, 2019

Published: July 31, 2019

Copyright () 2019 by author(s) and Scientific Research Publishing Inc. This work is licensed under the Creative Commons Attribution International License (CC BY 4.0).

http://creativecommons.org/licenses/by/4.0/

\begin{abstract}
The present study was conducted in the commune of Kérou in North Benin to measure the bioavailability of agricultural pesticides heavily used in the production of cotton on snails. The test was conducted in peasant environment in two villages of the commune. In each site, there are three cages containing 6 snails each. The snails are exposed to soil and plants without special protection and are therefore exposed to environmental conditions. Firstly it's to evaluate the presence or absence of agricultural pesticides in the viscera of snails after exposure. Secondly it consists to compare the different doses found in the viscera of snails in the different sites. And finally it's to evaluate the effect of the toxicity of the pesticides on the reproduction of snails. The tests consisted of placing steel cages in the two experimental sites. In each site, there are three cages containing 6 snails each. Snails are exposed to soil and plants without special protection and are therefore exposed to environmental conditions. The observations were made in order to establish a study of transfer kinetics. After the analysis of the data, it appears generally that the accumulation of mineral elements highlighted is not proportional to the mineralogical composition of the soil in which the snail is exposed. Total nitrogen and nitrate were significantly accumulated in the flesh of site 2 snails compared to site 1 snails. These different measures show the bioavailability of soil minerals for living organisms. Accumulations are not necessarily accompanied by toxic effects in terms of survival for snails after 28 days of exposure. However, the absence of immediate toxic effect on snails does not imply a lack of effect in food chains due to the trophic availability of contaminants. The use of snails as bio-indicator of soil quality has therefore proved relevant in the context of soils polluted by minerals.
\end{abstract}




\section{Keywords}

Bioavailability, Snail, Agricultural Inputs, Soil Pollution

\section{Introduction}

Soil is an essential resource for human societies and ecosystems. Not being a renewable resource on our human time scale and being subjected to increasing pressures (e.g. agricultural and forestry production, urban and industrial development, transportation networks...) and degradation (e.g.: erosion, atmospheric punctual and diffuse contaminations, compaction), it is now necessary to protect it in order to allow the sustainable development of societies [1]. In recent decades, economic and demographic pressures have led to rapid and massive degradation of exploited soils throughout the world.

For several years, the environmental risk of contaminated soils has been mainly addressed by physico-chemical methods. Although these analyses are necessary for the characterization of hazards, these tools do not make it possible to identify all of the molecules and/or toxic elements in multi-polluted contexts [2].

Indeed, the chemical analyses do not give sufficient information on the bioavailable fraction of the contaminants. Conversely, incorporating the effects from all contaminants, biological indicators are excellent ways to learn about the ecological state of polluted soil. In addition, knowledge of the bioavailability of minerals contaminants and the form in which they occur in the soil is a step necessary to determine ecotoxicological risks for living organisms in contaminated soil [3]. This bioavailability can be estimated via chemical measurements for estimating the mobile and provided fraction and biological measurements evaluating the absorption, the bio-accumulation and toxicity [4].

The present study aims to analyse the impact of the misuse of urea, an input that is heavily used in the production of cotton on snails (bioindicators of accumulation) living in these soils and indirectly to learn about the ecological status of the soils of the cotton basin of Benin. The snail is widely present in terrestrial ecosystems, so it is a mollusc that can tell us about the quality of the ecosystem in which it lives. It is exposed to pollution by several routes that involve the ingestion of contaminated food, contact and absorption by the foot epithelium from contaminated surfaces [5].

Snails are macro-invertebrates living at the soil-plant-air interface. They can have high densities [6]. These gastropod molluscs are phytophagous, scavengers and move on soil, lay in soil and ingest soil. They thus ingest multiple sources and routes of contamination [7]. Snails participate in the exchanges with the ground and are prey for many consumers (invertebrates: shining worms, larvae of carabes, or vertebrates: birds, small mammals such as shrews, hedgehogs and humans). 
In addition, the snail is an excellent bioindicator of terrestrial pollution. Because of its sedentary soil and herbivorous diet, it is easily contaminated by pollutants in the air, soil; hence the interest of its use as a test organism to assess the state of soil pollution in the commune of Kérou.

\section{Materials and Methods}

\subsection{Study Area}

The test was conducted in the commune of Kérou in the north-east of the Atacora department (Rep. of Benin). Of sudano-guinean type, the climate of the commune of Kérou is characterised by a rainy season, from mid-April to mid-October, and a dry season from mid-October to mid-April. It belongs to an agroecological zone characterised by an average rainfall of $1000 \mathrm{~mm}$ of water per year. The average temperature varies between $25^{\circ} \mathrm{C}$ in August and $31^{\circ} \mathrm{C}$ in April. The harmattan, a cold and dry wind, blows between December and mid-March sometimes resulting in a thermal amplitude of more than $10^{\circ} \mathrm{C}$.

The study area as a whole is located in a peneplain that stretches in the watershed between the basins of Niger and the Atlantic. But in the West, the terrain is mountainous with the presence of an arm of the Atacora ridge in the districts of Firou and Kaobagou. The study area has three types of soils, tropical ferruginous soils, ferralitic soils and hydromorphic soils found in swampy areas and lowlands (Figure 1).

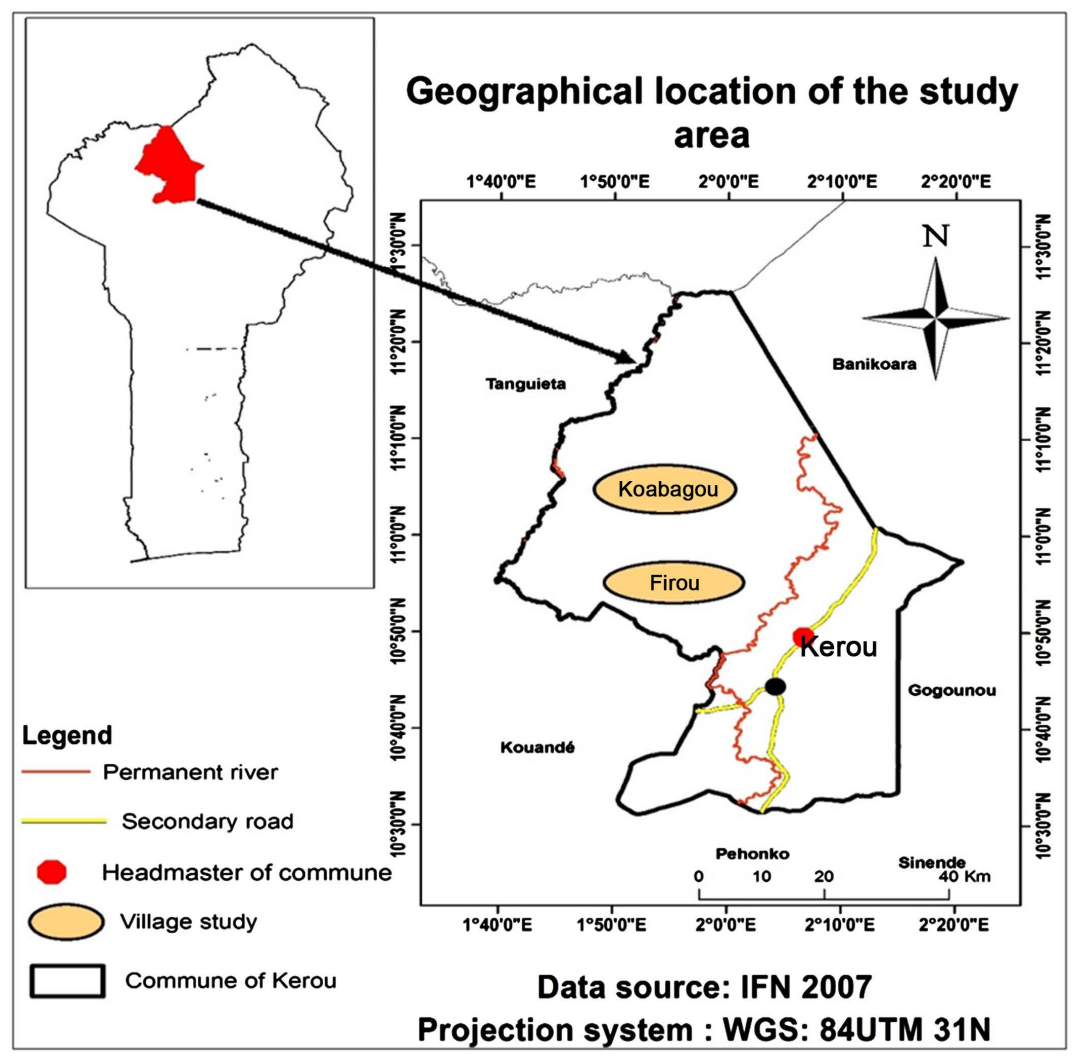

Figure 1. Map of the study area. 


\subsection{Equipment}

The material is first made up of snail (animal material). Caged snails are $50 \mathrm{~g}$ sub-adults raised for 3 months in potentially healthy environments. Microcosms are also used to encircle snails in exhibition environments.

\subsection{Methodology}

The general objective of this study is to evaluate the bioavailability of minerals on snails and analyse their impact on the dynamics of populations of snails in the commune of Kérou.

Firstly it's to evaluate the presence or absence of nitrate, ammonium, total nitrogen, total phosphorus and total potassium in the viscera of snails after exposure. Secondly it consists to compare the different doses found in the viscera of snails in the different sites. And finally it's to evaluate the effect of the toxicity of the pesticides on the reproduction of snails.

The tests consisted of placing steel cages in the two experimental sites. In each site, there are three cages containing 6 snails each. Snails are exposed to soil and plants without special protection and are therefore exposed to environmental conditions [8] [9] [10] [11].

The observations were made in order to establish a study of transfer kinetics. For this purpose, three snails are collected per site (i.e. one per cage) at each sampling date, i.e. the $14^{\text {th }}, 21^{\text {st }}$ and $28^{\text {th }}$ days after exposure. Observations on the behaviour of laying snails during exposure were also collected.

\subsection{Characteristics of the Different Exhibition Sites}

The test was conducted in peasant environment in two villages of the commune of Kérou. The first site is a field that is part of the intensification of agricultural production program. It receives a standard recommendation, but with a significant complement of compost. The cultural antecedent is known either two years of cotton production but always with a complement of beef manure.

The second site houses a $1 / 4$ hectare school farm and receives a dose of 50 $\mathrm{kg} / \mathrm{ha}$ of grass with a cultural antecedent, 3 successive years of intense cotton production (with the addition of mineral fertilizers only).

\subsection{Method of Analysis of Soil Samples and Snails}

\section{Mineralization and solubilization of soil and snail samples}

The solubilization method that is used is the mineralization by acid attack (mixture of hydrochloric acid and nitric acid) according to standard NF ISO 11,466 (aqua regia method) for soils and nitric acid etching only for the flesh of snails. It is carried out in a closed and hot environment $\left(150^{\circ} \mathrm{C}\right)$.

The samples, after acid etching and heating, are filtered using a filter paper. The filtrate obtained contains chemical elements to be assayed.

Dosage of elements with molecular absorption spectrophotometer (HACH DR 3800) 
In fact, the determination of these elements is made by the molecular absorption spectrometer type HACH DR 3800 according to the DR 3800 procedure manual. The principle is based on the measurement of a coloration developed by the sample in the presence of the element to be dosed in contact with the reagent used. The device passes a ray of a chosen wavelength through a tank containing the solution to be studied. The molecules of the solution absorb more or less the light ray and then the absorbance for this wavelength is defined. The intensity of this coloration is proportional to the concentration of the element in the sample.

\section{Expression of results}

The spectrometer displays directly to the computer the concentration of the element studied in the samples. These concentrations are expressed in $\mathrm{mg} / \mathrm{l}$. However, the actual concentrations $(C)$ of trace elements in organic products and soils are expressed in $\mathrm{mg} / \mathrm{kg}$ of dry weight. This concentration is calculated with the following equation:

$C(\mathrm{mg} / \mathrm{kg})=($ concentration of spectrometer $\times$ volume of filtration $) /$ Mass removed

\section{Data analysis method}

The results from the analysis of the different soil samples and snails were processed with the software Microsoft Excel and codified. The mineral accumulation curves were made with the same software (Microsoft Excel). The data was then submitted to analysis in the software $\mathrm{R}$ to determine the significance of mineral accumulation variations from one soil to another. Indeed, a test of normality was carried out on the snails of the two sites parameter by parameter in order to determine the type of test carried out to find the p-value. If normality is checked, Student test is performed and if not, we proceed to the Wilcoxon test.

\section{Results}

\section{Characterization of soils used for exhibitions}

The chemical composition of the soils of the two sites that hosted the test are recorded in Figure 2.

From the analysis of the soil samples from the two experimental sites, it is noted that the mineral element composition in the soil 2 shows a very high concentration of total nitrogen and nitrate compared to the control soil S1. Soil S2 shows a relatively low mineral component composition.

Evaluation of the contents of $\mathrm{N}, \mathrm{P}, \mathrm{K}, \mathrm{NHO}_{3}^{-}$and $\mathrm{NH}_{4}^{+}$in the snails after exposure to both environments

Figure 3 and Figure 4 show the evolution of the accumulation of tested elements as a function of the exposure time.

The accumulation of phosphorus and potassium elements in the snails of sites 1 and 2 are significantly different as proved by the two $p$-value $<0.05 \%$. On the phosphorus element, the data distribution is not normal. We therefore made a test of Wilcoxon to verify the significance of the difference in accumulation of elements (Figures 5-7). 


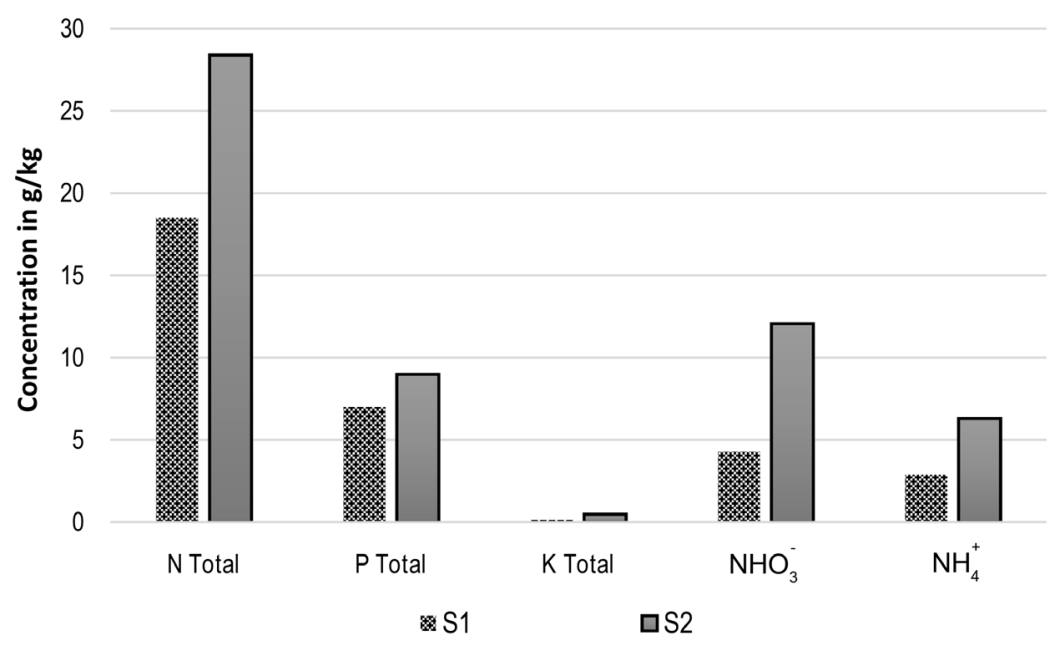

Figure 2. Mineralogical composition of soil samples from sites 1 and 2.

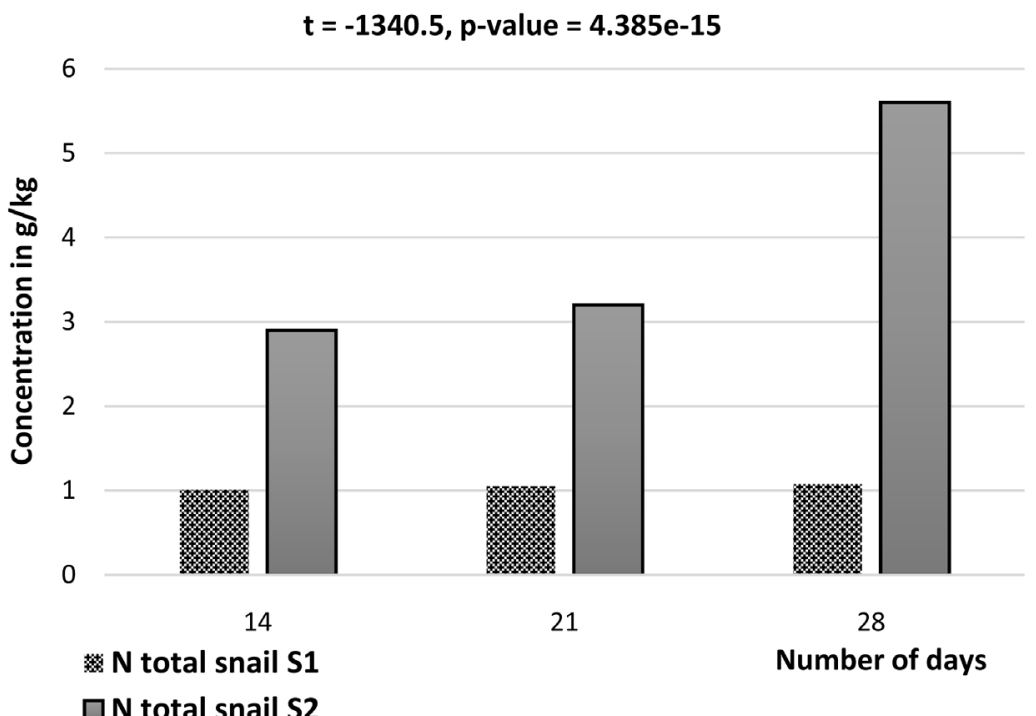

Figure 3. Kinetics of nitrogen accumulation in the flesh of snail during the exposure.

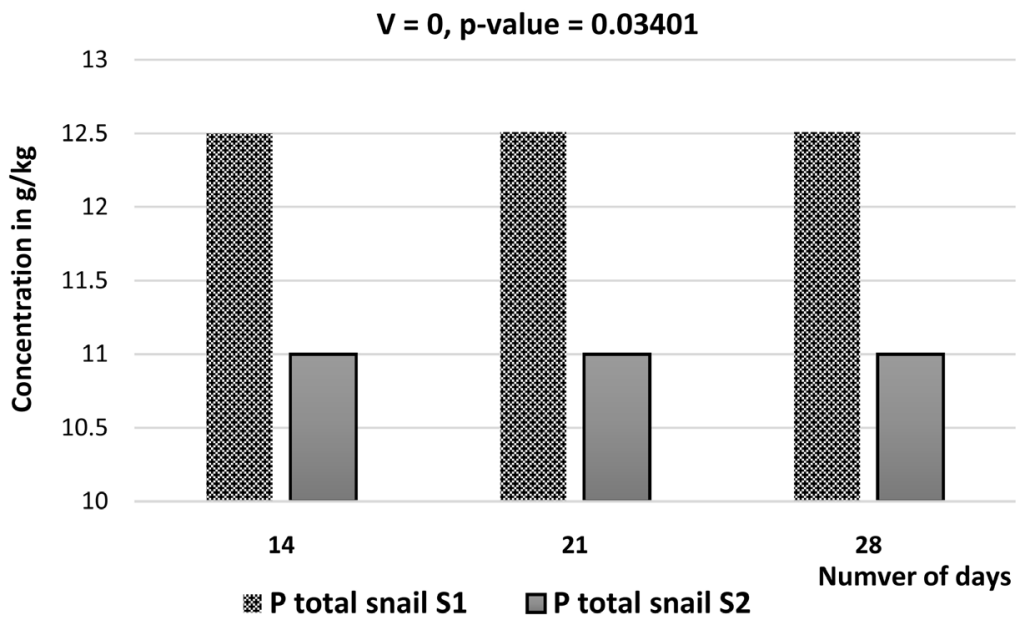

Figure 4. Kinetics of phosphorus accumulation in the flesh of snail during the exposure. 


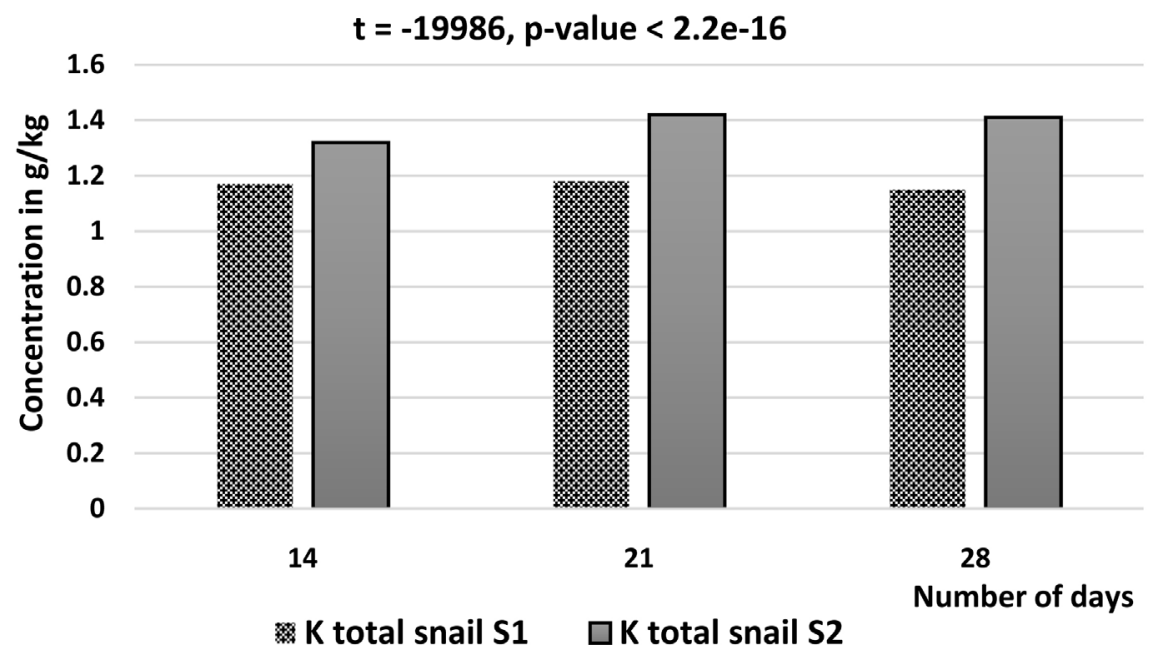

Figure 5. Kinetics of potassium accumulation in the flesh of snail during exposure.

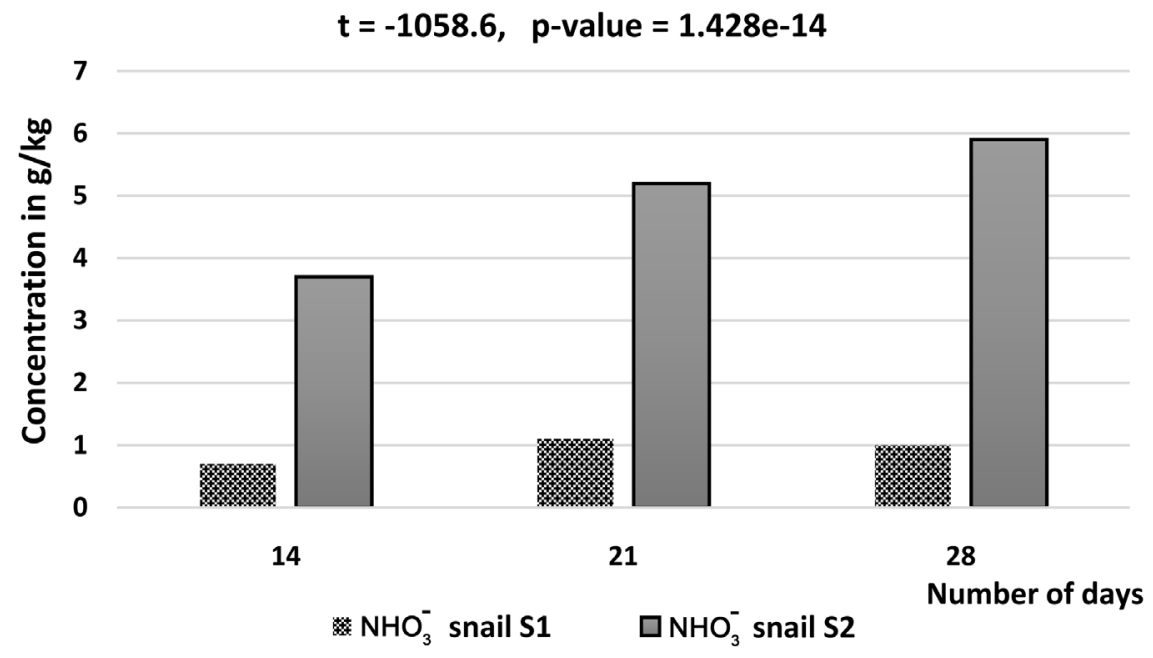

Figure 6. Kinetics of nitrate accumulation in the flesh of snail during exposure.

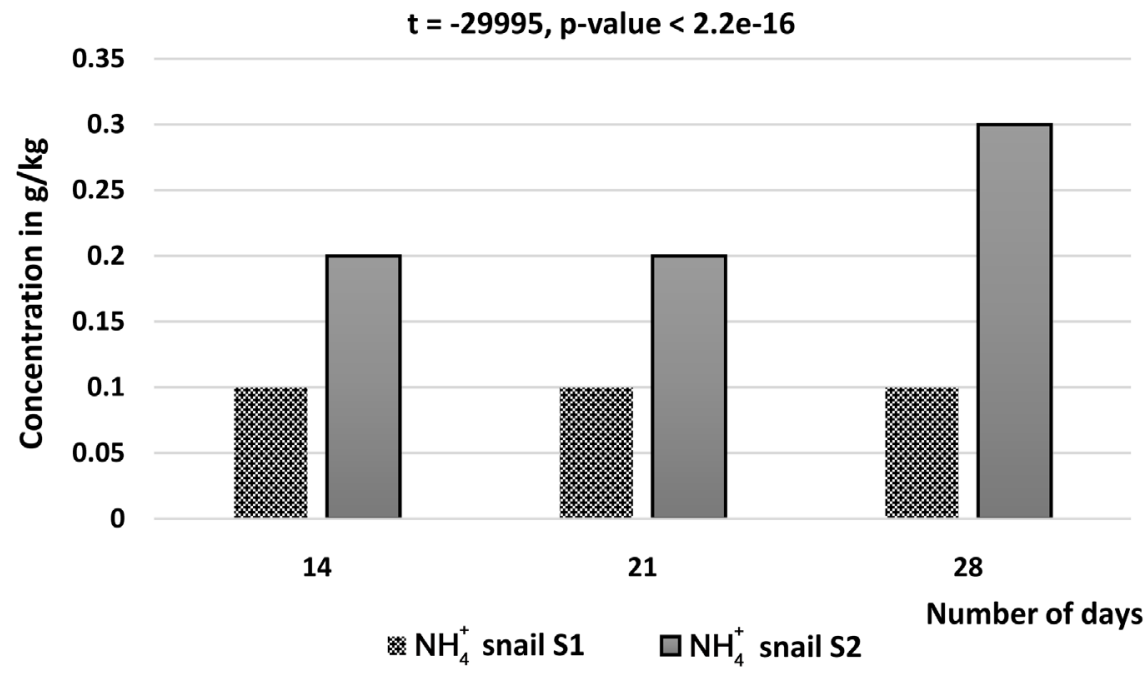

Figure 7. Kinetics of nitrite accumulation in the flesh of snail during exposure. 
In general, the accumulation of elements is not proportional to the mineralogical composition of the soil in which the snail is exposed. The minerals were accumulated differently and significantly in the snails of both soil types.

The total phosphorus, potassium and ammonium ion accumulated in both cases are higher than those found in the soils where they were exposed. The possible and valid explanation in these cases is that snails, even in a healthy state, contain within them phosphorus and potassium.

Total nitrogen and nitrate were significantly accumulated in snail flesh at site 2 compared to site 1 snails. These different measures show the bioavailability of soil minerals for the organisms that live there. Accumulations were not necessarily accompanied by toxic effects in terms of survival for snails after 28 days of exposure. However, the absence of immediate toxic effect on snails does not imply the absence of effect in food chains due to the trophic availability of contaminants because the snails exposed to the soil of site 2 have from the twenty-first day after exposure started by losing eggs significantly to other soil snails from site 1.

The difference in nitrate and total nitrogen accumulation observed at both sites is explained by the treatments received by each soil. Indeed, the soil 1 having been regularly treated with compost, the minerals available at this level are easily assimilated for the plant and the nitrification of the nitrogen is effective. This lowers the internal concentrations in snails after exposure. Conversely, at soil level 2, the recurrence of mineral fertilizers decreased the microbial activity of the soil as well as the absorbency of the plant. This makes difficult the assimilation of the minerals and is therefore free in the soil for the snails that live there.

Linking bioaccumulation with soil parameters and environmental availability is complex to analyse because snails are exposed not only to soil minerals but also to plant debris from cotton.

\section{Discussion}

The different results of accumulations as presented show a bioavailability of agricultural contaminants on snails and indirectly on other soil organisms. The transfer of contaminants was by skin diffusion through epithelia and by ingestion of soil particles as evidenced by Gomot et al. (1989) [12]. Indeed, the kinetics of accumulation of the elements evidenced varies according to the characteristics of the soil. This confirms the work of Pauget et al. (2012) [13] on the use of snails to measure the bioavailability of lead and cadmium, a first experiment that takes into account soil characteristics. In addition, the accumulation of minerals is not necessarily related to the internal concentration of minerals in the soil. For a judicious analysis of the risk of mineral transfer, it is therefore important to take into account their bioavailability, particularly by influencing the $\mathrm{pH}$ and soil organic matter in the snail [13]. This study therefore shows the inability of the total concentration of minerals to predict their bioavailability. 
The use of snails as a bioindicator of soil quality has proved relevant in the context of soils polluted by agricultural pesticides. The methodology used in this study provides information on the current bioavailability of snail contaminants and can also be used for ecosystem risk assessment and assessment of remediation methods.

Finally, under the current conditions of cotton production in Benin in general and in the commune of Kérou in particular, the intensive use of pesticides and other chemical fertilizers constitutes an important ecotoxicological risk for soil organisms and even for human health.

\section{Conflicts of Interest}

The authors declare no conflicts of interest regarding the publication of this paper.

\section{References}

[1] Bispo, A., Grand, C. and Galsomies, L. (2009) Le programme ademe "Bioindicateurs de qualité des sols": Vers le développement et la validation d'indicateurs biologiques pour la protection des sols. Etude et Gestion des Sols, 16, 145-158.

[2] ADEME-ADERA-LEB (2007) Aquitaine Transfert, ELISOL, Mines Saint-Etienne, EODD Ingénieurs Conseils. APPOLINE: Applicabilité à l'étude des sites pollués du biomarqueur lipidique des végétaux et du bio-indicateur nématofaune.

[3] Boudenne, J.L., Coulomb, B. and Prudent, P. (2011) Méthodes d'évaluation de la biodisponibilité des métaux lourds dans des sols contaminés. Université de Provence-CNRS-Laboratoire Chimie Provence-UMR 6264-Marseille.

[4] Michaud, A. (2016) Interaction entre biodisponibilité, phytotoxicité du cuivre et nutrition en fer de graminées-mécanismes physiologiques et rhizosphériques. Thèse École Nationale Supérieure Agronomique de Montpellier.

[5] Lalmi, S. and Lazreg, A. (2016) Effet de deux molécules nanométriques sur les paramètres physiologiques des escargots Helix aspersa. Mémoire de master en Science de la nature et de la vie. Université Larbi Tébessi-Tébessa, République Algérienne Démocratique et Populaire.

[6] Jeffery, S., Gardi, C., Jones, A., Montanarella, L., Marmo, L., Miko, L., Ritz, K., Peres, G., Römbke, J. and van der Putten, W.H. (2010) European Atlas of Soil Biodiversity. European Commission. Office of the European Union, Luxembourg.

[7] Vaufleury, A., Gimbert, F., Pauget, B., Fritsch, C. and Scheifler, R. (2014) Les Escargots bio-indicateurs de la qualite des sols-Snailwatch: Analyse en laboratoire ou in Situ de la biodisponibilité des contaminants. Fiche outil, 4.

[8] Gimbert, F., Mench, M., Coeurdassier, C., Badot, P.M. and de Vaufleury, A. (2008) Kinetic and Dynamic Aspects of Soil-Plant Snail Transfer of Cadmium in the Field. Environmental Pollution, 152, 736-745. https://doi.org/10.1016/j.envpol.2007.06.044

[9] Fritsch, C., Coeurdassier, M., Gimbert, F., Crini, N., Scheifler, R. and de Vaufleury, A. (2011) Investigations of Responses to Metal Pollution in Land Snail Populations (Cantareus aspersus and Cepaea nemoralis) from as Melter-Impacted Area. Ecotoxicology, 20, 739-759. https://doi.org/10.1007/s10646-011-0619-z

[10] Pauget, B., Gimbert, F., Coeurdassier, M., Scheifler, R. and de Vaufleury, A. (2011) 
Use of Chemical Methods to Assess $\mathrm{Cd}$ and $\mathrm{Pb}$ Bioavailability to the Snail Cantareus aspersus: A First Attempt Taking into Account Soil Characteristics. Journal of Hazardous Materials, 192, 1804-1811. https://doi.org/10.1016/j.jhazmat.2011.07.016

[11] De Vaufleury, A., Fritsch, C., Gimbert, F., Pauget, B., Coeurdassier, M., Crini, N. and Scheifler, R. (2009) Utilisation et intérêts des escargots et des micromammifères pour la bioindication de la qualité des sols. Etude et gestion des sols, 16, 203-217.

[12] Gomot, A., Gomot, L., Boukraa, S. and Bruckert, S. (1989) Influence of Soil on the Growth of the Land Snail Helix aspersa. An Experimental Study of the Route for the Stimulating Factors. Journal of Molluscan Studies, 55, 1-7.

https://doi.org/10.1093/mollus/55.1.1-a

[13] Pauget, B., Gimbert, F., Scheifler, R., Coeurdassier, M. and de Vaufleury, A. (2012) Soil Parameters as Key Factor to Predict Metal Bioavailability to Snails Using Chemical Extractants. Science of the Total Environment, 431, 413-425.

https://doi.org/10.1016/j.scitotenv.2012.05.048 